\title{
REVIEW
}

\section{Changing Agendas of CGIAR's International Agricultural Research}

\author{
Norihito KANAMORI $^{1 *}$ and Miyuki IIYAMA ${ }^{2}$ \\ ${ }^{1}$ Information and Public Relations Office, Japan International Research Center for Agricultural \\ Sciences, Tsukuba, Japan \\ ${ }^{2}$ Information Program, Japan International Research Center for Agricultural Sciences, Tsukuba, Japan
}

\begin{abstract}
For the past 50 years, agricultural research has contributed significantly to improving agricultural productivity for global food and nutrition security. The CGIAR, formerly the Consultative Group for International Agricultural Research, has been at the center of this effort. Accordingly, the orientation of CGIAR activities have profoundly changed over time from crop productivity improvement to broadened agendas, such as biodiversity conservation, environmental protection, and policy-related efforts. In parallel with the evolution of research orientation, the CGIAR also underwent operational reorganization. As the global food systems become more and more interconnected, and with global concerns about agriculture's contribution to overstepping the planetary boundaries and driving climate crises, the CGIAR has tried to consolidate operations among the CGIAR Research Centers to address research needs of smallholder farmers in the 21 st century. This review contextualizes the evolving role of the CGIAR vis-à-vis global challenges with reference to some highlights of Japan's contribution in each of the following periods: the 1970s; the 1980s-1990s; the 2000s-2010s; and onwards. This exercise can contribute to understanding the drivers affecting the global food systems in retrospective and subsequently deriving foresights for future directions of the food system transformation.
\end{abstract}

Discipline: Not applicable

Additional key words: food systems, the Green Revolution, globalization, the planetary boundaries

\section{Introduction}

For the past 50 years, agricultural research has contributed significantly to improving agricultural productivity for global food and nutrition security. The CGIAR, formerly the Consultative Group for International Agricultural Research, has been at the center of this effort. The CGIAR was established in 1971 with the participation of developed countries, including Japan which joined in 1972, international organizations such as Food and Agriculture Organization (FAO) and United Nations Development Programme (UNDP), Word Bank, regional development banks, and private foundations with experience in supporting agricultural research in developing countries (MOFA 2015). The CGIAR, which includes 15 CGIAR Research Centers related to agriculture, forestry, and fisheries, has collectively had greater impacts on agricultural production, productivity, and the livelihoods of the rural poor in the world than any other agricultural research organization (Evenson \& Gollin 2003, Pingali 2012). The CGIAR's work of public nature, through the provision of affordable food for hundreds of millions of people around the world, has been estimated to deliver benefits 10 times greater than the amount of investment (Renkow \& Byerlee 2010, Alston et al. 2020). Japan, as a funder, has contributed to effective and efficient management through decision-making.

Research agendas of the CGIAR have changed over the last fifty years, as the demands on agricultural research have grown more complex (CGIAR 2015). The CGIAR played a pivotal role in the Green Revolution through generating technological spillovers for poor people in countries with challenges in capacity to invest in agricultural research. Global food supply expanded faster than demand, and real food prices fell significantly, alleviating hunger and poverty by the second half of the 
20th century (Alston et al. 2020). Modern agriculture depending on external inputs, however, was developed for existing (more benign) climatic conditions and drawing on available biodiversity. Under further population pressures and growing resource scarcities, agriculture has become one of the prime drivers of overstepping the planetary boundaries and driving climate crises, while the world simultaneously suffering from burdens of hunger and unhealthy diets (Rockström et al. 2020). The 20th century model of agricultural development has thus been increasingly seen as outmoded, requiring fundamental transformation (GLOPAN 2020). Today, the CGIAR is expected to contribute to solving the complex challenges of the 21st century - providing healthy diets and rewarding employment for a wide range of social strata within the planetary boundaries. The CGIAR is proposing new contributions to the global food systems, by removing institutional barriers among its research centers toward impact-oriented research.

The CGIAR, being a frontrunner of agricultural research, celebrates its 50th anniversary in 2021. In the meantime, the global food security agendas have evolved dramatically, driven by constantly changing trends of demography, resource bases, income and technologies. This article looks back on the transition of the CGIAR in the context of the changing environment for international agriculture, forestry and fisheries research. Contextualizing the evolving role of the CGIAR vis-à-vis global challenges over the past half century or so, with reference to Japan's contribution, can contribute to understanding the drivers affecting the global food systems in retrospective and subsequently deriving foresights for future directions of the food system transformation.

\section{The evolution of CGIAR's mission and modes of operations}

The roots of what became the CGIAR date back to the 1940s, when a few far-sighted public and private agencies began making modest investments to improve the yields of staple crops in selected developing countries. By the 1960s, those investments had produced four fledgling international research centers (Fig. 1). The CGIAR was established in 1971 on the foundation laid by those centers as a funding and coordination mechanism for agricultural research centers that largely focuses on the tropics and subtropics (Alston et al. 2020, Byerlee \& Lynam 2020).

Since then, the global food security agendas have evolved dramatically, driven by constantly changing trends of demography, resource bases, income and technologies (Prager \& Wiebe 2021). Accordingly, the orientation of CGIAR activities have profoundly changed over time (Fig. 2). In the early 1970s, about $70 \%$ of CGIAR spending focused on staple crop productivity improvement, whose share had gradually reduced to less than a third of the total by the early 2000s. Since the 1980s-1990s, in turn, the

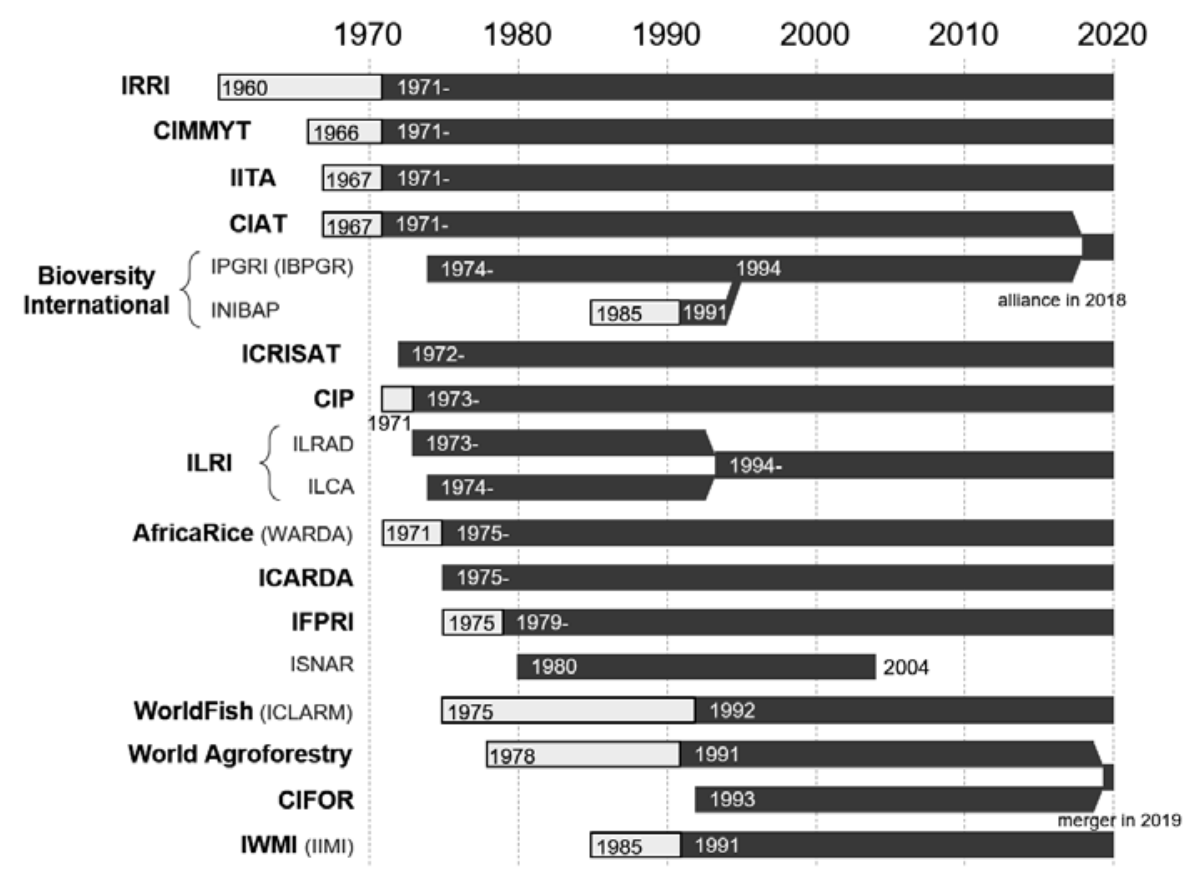

Fig. 1. The establishment of the research centers and the participation in the CGIAR. The 15 centers which existed as part of the CGIAR as of the late 2010s are shown in bold letters. Letters in parentheses indicate the former names of the institutes. See Table 1 for the official names. The bars after joining to the CGIAR were filled in gray. 
research scope of the CGIAR had broadened to include agendas such as biodiversity conservation, environmental protection, and policy-related efforts. Since the 21st century, the CGIAR has had to address the challenges facing the global food systems, amid drastically changing funding environment - peaking in 2014 then falling rapidly (Fig. 3) (Pingali 2001, Alston et al. 2020).

In parallel with the evolution of research orientation, the CGIAR also underwent operational reorganization to ensure that each center's research is maximized and that the CGIAR mission is accomplished. Below, we review the evolution of the CGIAR's missions and modes of operations vis-à-vis changing global agendas, with reference to some highlights of Japan's contribution in each of the following periods; the 1970s; the 1980s-1990s; the 2000s-2010s and onwards.

\section{1970s - the genesis of the CGIAR and crop research}

In the early 20th century, famine was rampant in the developing countries, triggered by crop failures often aggravated by socio-political factors. Feeding a rapidly growing population became the global agenda and formed the context which prioritized the universal supply of sufficient calories from staple crops in the post-WWII period. The founders of the CGIAR were convinced that new, science-based agricultural technologies could be effective weapons to eradicate hunger and poverty (CGIAR 2015, Byerlee \& Lynam 2020). In this context, International Rice Research Institute (IRRI), International Maize and Wheat Improvement Center (CIMMYT), International Institute of Tropical Agriculture (IITA), and International Center for Tropical Agriculture (CIAT) were established in the 1960s (Fig. 1).

The CGIAR was launched in 1971 to link the research

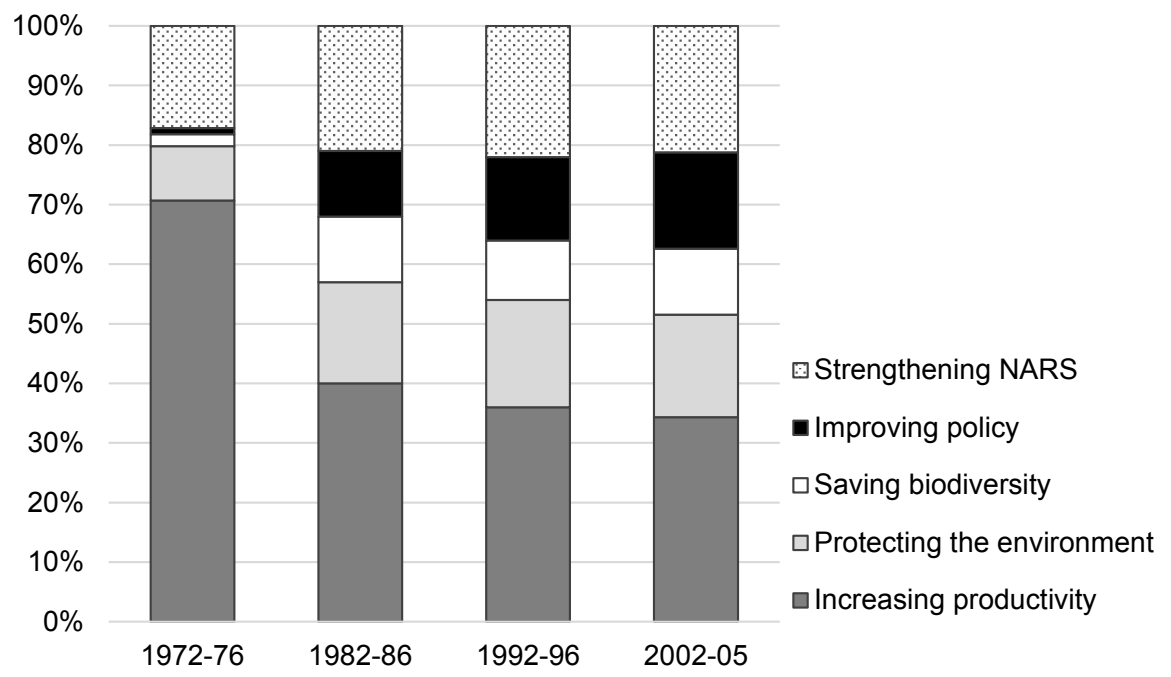

Fig. 2. Expenditure of funds by sector.

NARS: National Agricultural Research System. Source: Alston, Pardey and Rao (2020)

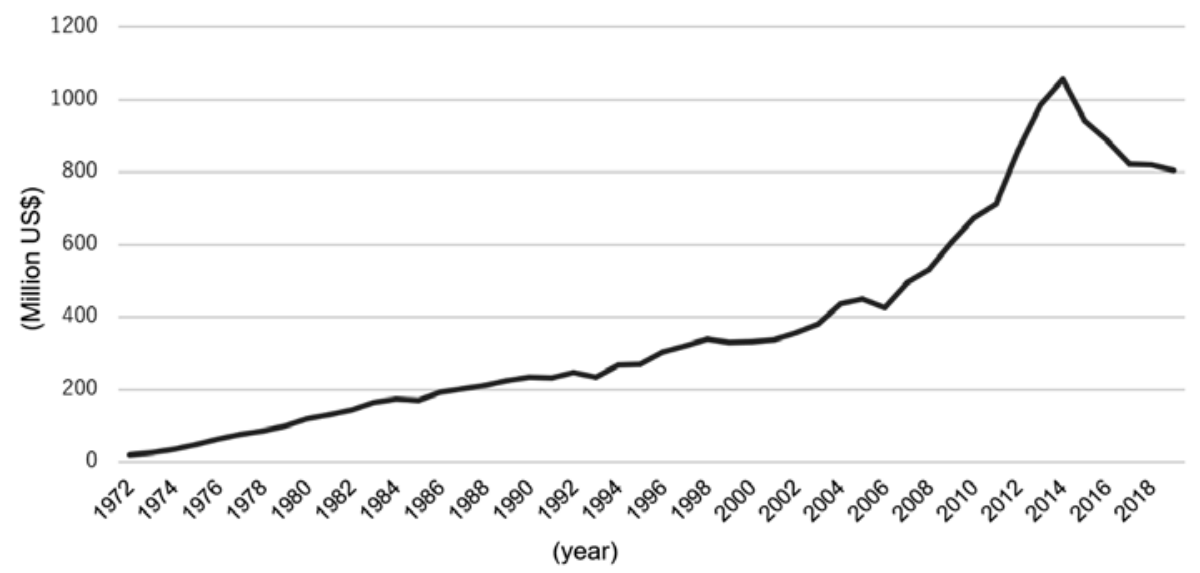

Fig. 3. The trend of total funding to the CGIAR.

Data: CGIAR (1997b, 2000, 2005, 2007, 2011c, 2020e, 2020f) 
centers -namely, IRRI, CIMMYT, CIAT and IITA, as the implementing centers of a consultative group of funders under the leadership of the World Bank. The consultative group included the Food and Agriculture Organization of the United Nations (FAO), the United Nations Development Program (UNDP), and other organizations, with the participation of developed countries including Japan, which joined in 1972, regional development banks, and private foundations with experience in supporting agricultural research in developing countries, including particularly the Rockefeller and Ford Foundations who had been the originators of the centers of excellence idea for research in tropical agriculture (CGIAR 2011b, MOFA 2015). The centers added during the 1970s, all except International Food Policy Research Institute (IFPRI), which focused on crop and livestock productivity. They were; International Crops Research Institute for the SemiArid Tropics (ICRISAT); International Potato Center (CIP); International Laboratory for Research on Animal Diseases (ILRAD) and International Livestock Centre for Africa (ILCA), which were merged to form International Livestock Research Institute (ILRI) in 1994; International Plant Genetic Resources Institute (IPGRI, currently Bioversity International); West Africa Rice Development Association (WARDA, currently AfricaRice); and International Center for Agricultural Research in the Dry Areas (ICARDA) (Fig. 1, Alston et al. 2020).

The development of modern or high-yielding crop varieties (MVs) of rice and wheat for developing countries had begun in a concerted fashion in the late 1950s. The release and dissemination of MVs among farmers in Asia and Latin America during the 1960s was driven by IRRI and CIMMYT (Evenson \& Gollin 2003). The development of MVs combined with the use of chemical fertilizers and irrigation, greatly increased productivity and demonstrated the potential of agricultural research to contribute to solving food problems in developing countries. This success was characterized as a "Green Revolution" and often attributed to the work of the CGIAR which generated and disseminated knowledge, invention, and products of "public goods" nature (Evenson \& Gollin 2003, Pingali 2012). The CGIAR's numerous crop improvement networks with NARS as well as academic institutions allowed for the best breeding materials and knowledge to be widely and freely available and used across diverse agroecological environment in the developing world. Such an uninhibited system of germplasm exchange with the best international materials allowed countries to make strategic decisions about investing in plant breeding capacity (Pingali 2012). Japan's contribution to the Green Revolution is also notable, mainly through joint research with IRRI to intensify rice production. Around 1,000 MVs of rice released in South and Southeast Asia since the 1960-1970s were linked to germplasm developed by IRRI and its partners, including Japan (Saito 2006).

Thanks to the technological breakthroughs, cereal production expanded faster than the population growth, providing sufficient calories to people at affordable costs and averting global famines, without the necessity to expand extra land for production (Pingali 2012, Alston et al. 2020). Productivity gains from the Green Revolution, however, have been uneven across crops and regions (Evenson \& Gollin 2003). In the early period of the Green Revolution (1966-1985), public investment in crop genetic improvement built on the advancements in the developed world for the major staple crops and adapted them to the conditions of developing countries (Pingali 2012). For many other crops which could not rely on prior work in developed countries, or for regions with marginal conditions, the development and dissemination of improved varieties came later (Evenson \& Gollin 2003, Prager \& Wiebe 2021).

\section{The 1980s - 1990s: the broadening of the scope of the CGIAR's research agendas}

The Green Revolution succeeded in achieving its ultimate goal - the eradication of famines. In turn, agriculture, food systems, and their drivers are constantly evolving, so the solutions that worked to solve a particular problem in a particular moment are not stationary in time (Prager \& Wiebe 2021). By the 1980s-1990s, the world faced serious environmental concerns such as water and wind erosion, loss of soil nutrients, salinization, water logging, tropical deforestation, and loss of biodiversity. Agriculture was seen at the center of any effective solution to the nexus of problems encompassing population growth, environmental destruction, poverty, and food insecurity (CGIAR 1997a). New modes of agriculture were called for to face the new realities of the late 20th century world to feed the population, projected to grow from 4.5 billion in 1980 to 6 billion in 2000, with increasingly scarcer resources, compared to 3 billion in 1960 and 3.7 billion in 1970.

Correspondingly, the CGIAR decided to broaden its research mandates from solely focusing on improving productivity, to including topics such as, protecting the environment, saving biodiversity, and improving policies (Fig. 2, CGIAR 1997a). This led to the significant expansion of the CGIAR Research Centers in the scope of science and subject matter covered beyond crops (Alston et al. 2020). The following centers were added during the 1980s and 1990s - International Service for National Agricultural Research (ISNAR), International Council for Research in Agroforestry (ICRAF, currently 
World Agroforestry), International Water Management Institute (IWMI), International Center for Living Aquatic Resources Management (ICLARM, currently WorldFish) and Center for International Forestry Research (CIFOR) (Fig. 1, Alston et al. 2020).

This 1980s-1990s was also among the most fruitful periods in the long history of Japan-CGIAR collaborative research. In 1995, Japan was the CGIAR's second-largest donor, as the Japanese government provided \$33.9 million, or 12.6 percent, of the CGIAR's total funding (Saito 2006). There were many collaborative research projects with Japanese universities, research institutes and development agencies implemented during the period. Examples included; a joint ILRI-JIRCAS research on parasites causing east coast fever to African livestock; a third-phase ICRISAT-JIRCAS project on soil fertility in the semi-arid tropics; the first efforts to breed the New Rice for Africa (NERICA) at AfricaRice; secondment of JIRCAS researchers to ICARDA to develop sustainable rangeland management in West Asia and North Africa; IITA-JICA collaboration to develop tofu processing in Nigeria; research on the yacon, a nutritious root vegetable, at CIP; contribution to CIFOR's sustainable forest management research; support to WorldFish' effort to improve genetic improvement of fish resources; funding of the construction of World Agroforestry's research buildings as well as contribution to research on restoring soil fertility in Africa with nitrogen-fixing legumes; a Japanese fellow's research at IFPRI on land tenure and forest resource management; assignments of four Japanese scientists at IWMI to work on monitoring and modeling efficient water use; collaboration between Japanese institutions and Bioversity International on germplasm collection and improvement, including the collection of Japonica rice varieties; Japan-CIAT collaboration on research of endophytes in tropical grasses; along with Government of Japan's long-term financial commitments to IRRI and CIMMYT (Saito 2006).

\section{The 2000s - 2010s: the food system challenges in the globalized world}

The first decade of the 21st century witnessed the acceleration of globalization - the movement of goods, people, money, and information through international trade and financial markets - and the widening of global imbalances as the developing countries became more integrated into the global economy (UNCTAD 2012). Some emerging economies, notably China, increased their economic and political prominence, and also became dominant players in the agricultural commodity market both as producers and as consumers. In contrast, many countries in South Asia and sub-Saharan Africa failed to keep pace of the agricultural transformation and economic development under increasing impacts of climate change as well as their inability to trade in the global marketplace (Schmidhuber \& Tubiello 2007). The inherent risk of the interconnectedness of the global food systems culminated at the 2008 food crisis. Between June 2006 and June 2008, food prices rose 2.3 times nominally and doubled in real terms, inducing political unrest in food-importing developing countries as a result of multitudes of combined factors. They included; drought in grain-producing countries, escalation of the biofuel boom due to rising crude oil prices, global speculative money flowing into the grain market due to a reduction in interest rates, and in addition to these factors, structural changes in food demand in Asia (Headey 2011).

One of the effects of the spike in global food prices was to refocus attention on agriculture and its interconnectivities. There was also the realization that agriculture was entwined with many development and environmental pathways and that single commodity improvement programs would contribute to productivity but would not address the broader dimensions of agriculture and food system connections. For this reason, the CGIAR started to experiment and develop system approaches to research under the increasingly interconnected food systems. In 2008, CGIAR embarked on a transformation process to improve coordination among all stakeholders involved in international agricultural research for development including donors, researchers and beneficiaries, and to refocus the efforts of the CGIAR Research Centers on major global development challenges that might be addressed through agricultural research (Sierra et al. 2008). In the context of rising global investments in agricultural R\&D, total funding for the CGIAR peaked at over \$1 billion in 2014 after a surge in response to the global food crisis (Fig. 3). A key objective of this reform was to integrate the work of the centers and their partners, avoiding fragmentation and duplication of effort, while organizing the governance functions and separating the fund management functions. As a result, the CGIAR Consortium and the CGIAR Fund were established in 2010 (CGIAR 2011a, CGIAR 2011b) to develop, fund and manage research in a more comprehensive fashion across the centers. Until then, all donors, including developing countries, were eligible to become members of the CGIAR, but as the number increased, the members of the CGIAR Fund Council were selected based on regional balance (CGIAR 2010). Afterwards, for effective, efficient, and transparent governance and effective leadership to mobilize financial support, further reform was undertaken and the new CGIAR System has been in place since 2016 (Table 1). 


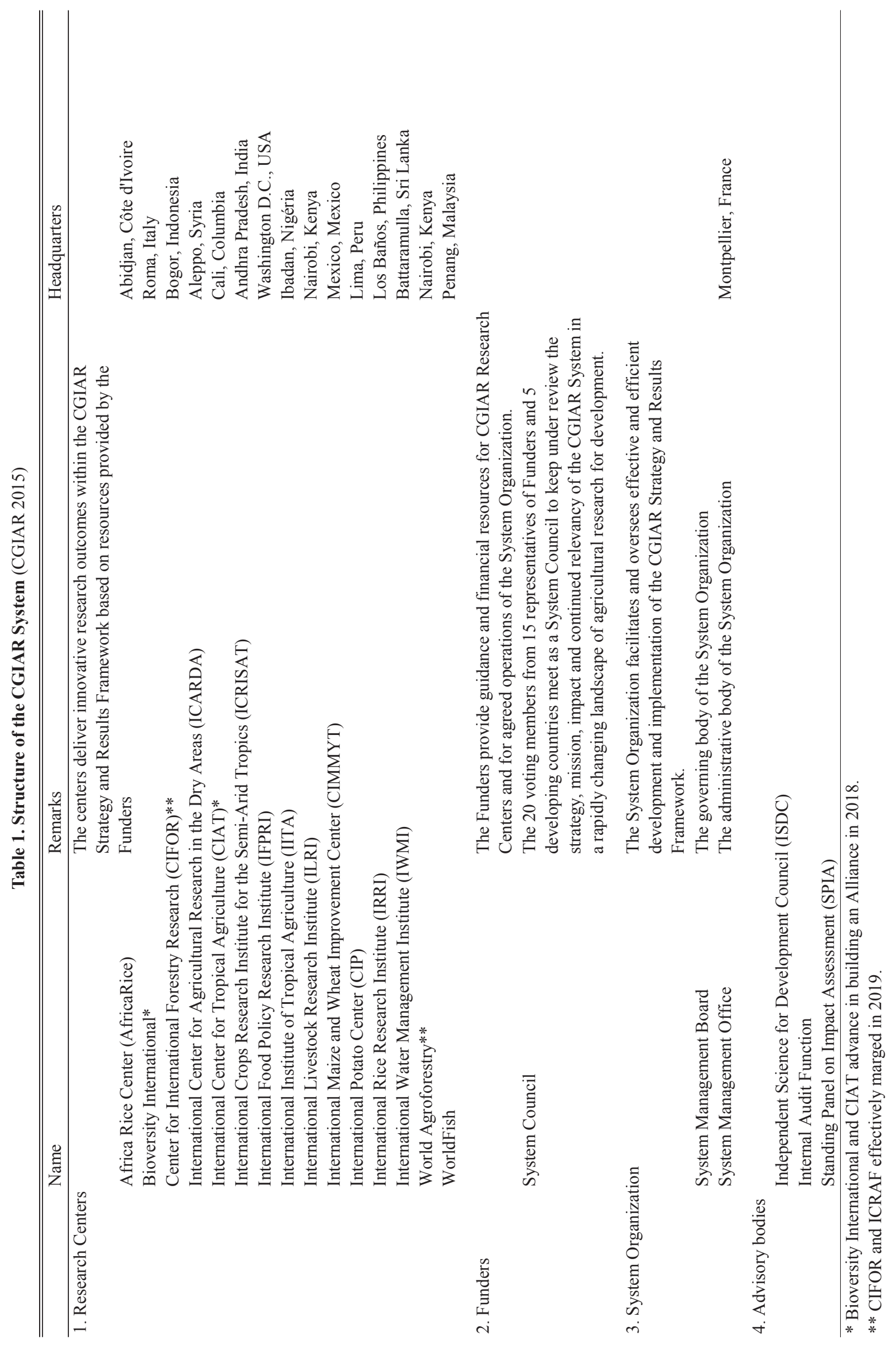


The work of the CGIAR has been governed by an umbrella organization called the CGIAR System Council, which conducts its meetings between representatives of Funders and developing countries (Table 1). Japan has contributed greatly to this series of reforms and has also dispatched Japanese officers to the System Management Office from 2017 to 2019 to develop the CGIAR Performance Report (CGIAR 2020c) and Dashboard (CGIAR 2020d), as well as to promote joint research between researchers in CGIAR Research Centers and Japan.

The CGIAR Strategy and Results Framework was a document and an approach which launched the CGIAR Research Programs (CRPs) with its first phase (2011-2016) and the second phase (2017-2021) (Table 2). CRPs were multi-center, multi-partner initiatives to deliver impacts on CGIAR's system-level outcomes (SLOs), i.e. reducing poverty; improving food and nutrition security; improving natural resources and ecosystem services. The CRPs of the first phase were developed to provide broader outcomeoriented programs with CGIAR Research Centers forming collaborative links with each other and with other research and development partners independently, but there was less CRP-to-CRP linkage. From the second phase, all CRPs have been designed to enhance collaboration among CRPs as well as among centers and partners and fall into two categories: the Agri-Food System (AFS) focusing on agriculture and food systems, and Global Integrating
(GI) as cross-cutting programs to provide frameworks for addressing global issues beyond crops and regions such as nutrition for health, climate change, policy, and natural resources and ecosystems (Table 3). In addition, four platforms supported the activities of the CRPs in the areas of maintenance, management, and use of genetic resources, use of advanced breeding technologies, use of big data analysis using diverse information, and gender equality at the forefront of global agricultural research for development.

\section{Onwards: the planetary boundaries and food system challenges}

By today, the global food system has the capacity to produce, at face value, the volume of food sufficient to feed 7.8 billion people. However, the success of the 20th century model of focusing on staple crops and providing calorie-dense food at reduced costs has increasingly revealed that it fails to address other dimensions of nutrition security and food safety, at great cost of both human and planetary health. Today, the world faces the triple burden of malnutrition and poor-quality diets are now among leading causes of deaths. At the same time, agriculture, forestry and other land use sector, and more broadly the food system including the value chain, are now among leading drivers of pushing the Earth system beyond the boundaries of sustainability, accounting a quarter and

Table 2. CGIAR's Vision, Mission, and Goals (CGIAR 2015)

\begin{tabular}{|c|c|}
\hline Vision & A world free of poverty, hunger and environmental degradation. \\
\hline Mission & $\begin{array}{l}\text { To advance agricultural science and innovation to enable poor people, especially } \\
\text { women, to better nourish their families, and improve productivity and resilience } \\
\text { so they can share in economic growth and manage natural resources in the face of } \\
\text { climate change and other challenges. }\end{array}$ \\
\hline Goals, or System Level Outcomes (SLOs) & (Targets at 2030) \\
\hline \multirow[t]{2}{*}{ 1. Reduce poverty } & $\begin{array}{l}350 \text { million more farm households have adopted improved varieties, breeds or trees, } \\
\text { and/or improved management practice }\end{array}$ \\
\hline & 100 million people, of which $50 \%$ are women, assisted to exit poverty \\
\hline \multirow[t]{4}{*}{$\begin{array}{l}\text { 2. Improve food and nutrition security } \\
\text { for health }\end{array}$} & $\begin{array}{l}\text { Improve the rate of yield increase for major food staples from current }<2.0 \text { to } 2.5 \% \text { / } \\
\text { yearix }\end{array}$ \\
\hline & $\begin{array}{l}150 \text { million more people, of which } 50 \% \text { are women, meeting minimum dietary } \\
\text { energy requirements }\end{array}$ \\
\hline & $\begin{array}{l}500 \text { million more people, of which } 50 \% \text { are women, without deficiencies of one or } \\
\text { more of the following essential micronutrients: iron, zinc, iodine, vitamin A, folate, } \\
\text { and vitamin B12 }\end{array}$ \\
\hline & $\begin{array}{l}33 \% \text { reduction in women of reproductive age who are consuming less than the } \\
\text { adequate number of food groups }\end{array}$ \\
\hline \multirow[t]{4}{*}{$\begin{array}{l}\text { 3. Improve natural resource systems and } \\
\text { ecosystem services }\end{array}$} & $\begin{array}{l}20 \% \text { increase in water and nutrient (inorganic, biological) use efficiency in agro- } \\
\text { ecosystems, including through recycling and reuse }\end{array}$ \\
\hline & $\begin{array}{l}\text { Reduce agriculturally-related greenhouse gas emissions by } 0.8 \mathrm{Gt} \mathrm{CO} \text {-e yr-1 (15\%) } \\
\text { compared with a business-as-usual scenario in } 2030\end{array}$ \\
\hline & 190 million hectares (ha) degraded land area restored \\
\hline & 7.5 million ha of forest saved from deforestation \\
\hline
\end{tabular}


Table 3. CGIAR Research Portfolio 2017-2021

\begin{tabular}{|c|c|}
\hline CGIAR Research Programs and Platforms & Remarks \\
\hline 1. Agri-Food Systems CGIAR Research Programs & $\begin{array}{l}\text { Agri-Food Systems involve adopting an integrated, agricultural } \\
\text { systems approach to advancing productivity, sustainability, } \\
\text { nutrition and resilience outcomes at scale. }\end{array}$ \\
\hline Fish & https://fish.cgiar.org/ \\
\hline Forests, Trees and Agroforestry (FTA) & https://www.foreststreesagroforestry.org/ \\
\hline Grain Legumes and Dryland Cereals (GLDC) & http://gldc.cgiar.org/ \\
\hline Wheat & https://wheat.org/ \\
\hline Livestock & https://livestock.cgiar.org/ \\
\hline Maize & https://maize.org/ \\
\hline Rice & http://ricecrp.org/ \\
\hline Roots, Tubers and Bananas (RTB) & https://www.rtb.cgiar.org/ \\
\hline 2. Global Integrating Research Programs & $\begin{array}{l}\text { Cross-cutting Global Integrating Programs framed to work } \\
\text { closely with the Agri-Food Systems Programs within relevant } \\
\text { agro-ecological systems. }\end{array}$ \\
\hline Agriculture for Nutrition and Health (A4NH) & http://a4nh.cgiar.org/ \\
\hline Climate Change, Agriculture and Food Security (CCAFS) & https://ccafs.cgiar.org/ \\
\hline Policies, Institutions, and Markets (PIM) & http://pim.cgiar.org/ \\
\hline Water, Land and Ecosystems (WLE) & https://wle.cgiar.org/ \\
\hline 3. Research Support Platforms & $\begin{array}{l}\text { Platforms underpin the research of the whole system and support } \\
\text { Research Programs. }\end{array}$ \\
\hline Big Data in Agriculture & https://bigdata.cgiar.org/ \\
\hline Excellence in Breeding (EiB) & https://excellenceinbreeding.org/ \\
\hline Genebank & https://www.genebanks.org/ \\
\hline GENDER & https://gender.cgiar.org/ \\
\hline
\end{tabular}

a third of anthropogenic greenhouse gas (GHG) emissions respectively (Rockström et al. 2020).

To feed 10 billion people by 2050 within the planetary boundaries, successful innovation for the radical transformation of food systems is urgently called for to minimize GHG emissions in all the stages, from production, processing, distribution to consumption (Willet et al. 2019, Campos 2020, GLOPAN 2020). At the same time, the daunting task of eradicating poverty and hunger remains, with still more than 800 million people suffering from undernutrition (United Nation 2019a, United Nation 2019b), whose figures are expected to rise due to the COVID-19. Two-thirds of people suffering from hunger live in rural areas, and many of them derive livelihoods from land (smaller than 2 hectares), making rural poverty almost identical with food insecurity of smallholders. Amid the worrying trend in which the overwhelming majority of agricultural studies are shifting their focus away from ending poverty, the CGIAR stands out with its continued and renewed commitment to smallholders (Nature Editorial 2020).

In recent years, however, high-income countries have scaled back their support for international agricultural research, and total funding for the CGIAR peaked in 2014, has fallen rapidly. Although Japan's financial support has decreased significantly in recent years, Japan, as a voting member of the CGIAR System Council in the CGIAR System, has contributed to effective and efficient management through decision-making with the cumulative amount of contributions to date is $\$ 730$ million, ranking 7th in the world. (CGIAR 2020a) (Fig. 4).

The above funding trends have raised concern about the capacity of the world to sustainably reduce global hunger and poverty over the coming decades, and about the ability of the NARS in developing countries, working in concert with the CGIAR, to provide the requisite technologies (Alston et al. 2020). The CGIAR has responded to the growing demand for its contribution to smallholder farmers under shrinking resources by renewing its effort to consolidate operations into a common research and innovation strategy, One CGIAR. One CGIAR is expected to jointly tackle the pressing global needs under a globally mandated Executive Management Team, as a unified structure in place of 15 separate CGIAR Research Centers each focusing on its own specific strategy and mandate (CGIAR 2020b). As One CGIAR, by focusing on a few key entry points for research which will have maximum effects on the various dimensions of the food 


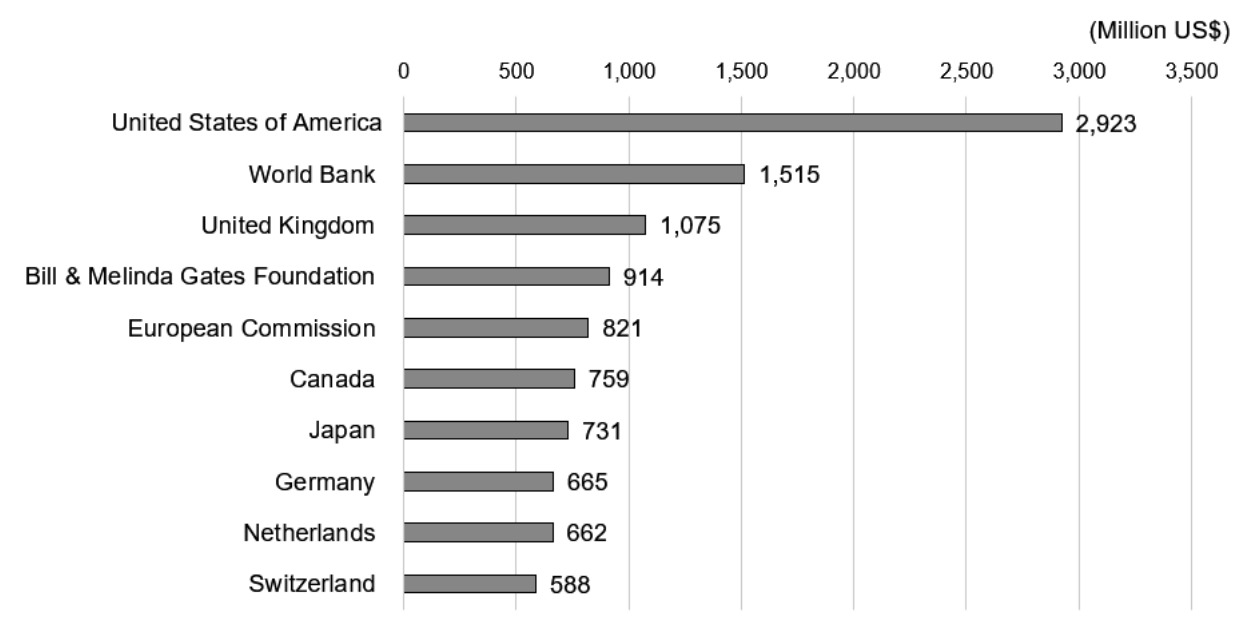

Fig. 4. Culminative financial contributions (1972-2019) of the top donors to the CGIAR. Data: CGIAR $(2010,2020 \mathrm{e}, 2020 \mathrm{f})$

system puzzle, it is expected that scientific innovations for food, land and water systems can be deployed faster, at a larger scale, and at reduced cost, having greater impact where they are needed the most (CGIAR 2021).

\section{Conclusion}

The CGIAR has contributed significantly to improving agricultural productivity for global food and nutrition security. Since joining the CGIAR in 1972, Japan has made significant contributions to the CGIAR by supporting effective and efficient operation and by supporting research in many CGIAR Research Centers. Over the half century of CGIAR's existence, the world population doubled from 3.7 billion in 1970 to 7.8 billion in 2020. While the world succeeded in eradicating famines in the developing countries, the challenges have become more complicated, diverged and localized. Some of the developing countries which had suffered from chronic food insecurity by the mid-20th century have achieved not only food security for the majority of its population but also observed changes in food demand both in quality and in quantity, with new forms of malnutrition- overweight and obesity emerging. In contrast, smallholder farmers in many developing countries have still suffered from food and nutrition insecurity due to underperformance of their agriculture sector, which has become increasingly vulnerable to vagaries of climate uncertainties and environmental degradation.

The CGIAR has been instrumental in humanity's efforts to eradicate poverty and hunger by the provision of world-class science, technology and innovation as "public goods", and through its effective network among the centers as well as NARS and increasingly public and private research partnerships. This kind of facilitation the
CGIAR has provided will remain essential in the coming decades to achieve the sustainable transformation of the global food systems to serve for both human and the planet. Success in achieving a positive transformation of the food system and societies will depend on effectively delivering localized solutions to address fundamental bottlenecks smallholder farmers face in specific local contexts. Mobilization of state-of-the art science, technology, and innovation are critical.

\section{Acknowledgement}

We are sincerely grateful for the valuable comments given by Dr. Peter Gardiner, former Senior Advisor, Programs of CGIAR.

\section{References}

Alston, J. M. et al. (2020) The Payoff to Investing in CGIAR Research. SoAR Foundation.

Byerlee, D. \& Lynam, J. K. (2020) The development of the international center model for agricultural research: A prehistory of the CGIAR. World Dev., 135, 105080.

Campos, H. (2020) The Quest for Innovation: Addressing user needs and value creation. The Innovation Revolution in Agriculture. Springer, pp.1-31.

CGIAR (1997a) CGIAR Annual Report 1995-1996 25th Anniversary. CGIAR Secretariat.

CGIAR (1997b) CGIAR 1996 Financial Report. CGIAR Secretariat.

CGIAR (2000) CGIAR Financial Report 1999. CGIAR Secretariat.

CGIAR (2005) CGIAR Financial Report 2004. CGIAR Secretariat.

CGIAR (2007) CGIAR Financial Report 2006. CGIAR Secretariat.

CGIAR (2010) CGIAR Fund Governance Framework. CGIAR Fund Office. 
CGIAR (2011a) Changing Agricultural Research in a Changing World. CGIAR Consortium Office.

CGIAR (2011b) CGIAR Annual Report 2011. CGIAR Consortium Office.

CGIAR (2011c) CGIAR Financial Report 2010. CGIAR Consortium Office.

CGIAR (2015) CGIAR Strategy and Results Framework 20162030. CGIAR Consortium Office.

CGIAR (2020a) Composition. https://www.cgiar.org/how-wework/governance/system-council/sc-composition/. Accessed on 24 Dec 2020.

CGIAR (2020b) One CGIAR - endorsed destination, transition roles, and time line. https://storage.googleapis.com/ cgiarorg/2020/05/One-CGIAR-endorsed-destinationtransition-roles-timeline.pdf. Accessed on 24 Dec 2020.

CGIAR (2020c) Performance Report 2019. https://www.cgiar. org/annual-report/performance-report-2019/. Accessed on 24 Dec 2020.

CGIAR (2020d) Dashboard. https://www.cgiar.org/dashboards/. Accessed on 24 Dec 2020.

CGIAR (2020e) CGIAR Trust Fund Contributions. https:// www.cgiar.org/funders/trust-fund/trust-fund-contributionsdashboard/. Accessed on 24 Dec 2020.

CGIAR (2020f) Funder Analysis. https://www.cgiar.org/foodsecurity-impact/finance-reports/dashboard/funder-analysis/. Accessed on 24 Dec 2020.

CGIAR (2021) CGIAR 2030 Research and Innovation Strategy: Transforming food, land, and water systems in a climate crisis. CGIAR System Organization.

Evenson, R. E. \& Gollin, D. (2003) Assessing the impact of the green revolution, 1960 to 2000. Science, 300, 758-762.

Headey, D. (2011) Rethinking the global food crisis: The role of trade shocks. Food Policy, 36, 136-146.

MOFA (2015) https://www.mofa.go.jp/mofaj/files/000106431. pdf. Accessed on 24 Dec 2020. [in Japanese].

Nature Editorial (2020) To end hunger, science must change its focus. Nature, 586, pp. 336.

Pingali, P. L. (2001) Milestones in Impact Assessment Research in the CGIAR, 1970-1999. With an Annotated Bibliography of Impact Assessment Studies Conducted in the CGIAR, 1970-1999. CIMMYT.

Pingali, P. L. (2012) Green Revolution: Impacts, limits, and the path ahead. PNAS, 109, 12302-12308.

Prager, D. \& Wiebe, K. (2021) Strategic foresight for agriculture: Past ghosts, present challenges, and future opportunities, Global Food Security, 28, 2021.

Renkow, M. \& Byerlee, D. (2010) The impacts of CGIAR research: A review of recent evidence, Food Policy 35, 391402.

Rockström, J. et al. (2020) Planet-proofing the global food system. Nat. Food, 1, 3-5.

Saito, M. (2006) Japan and the CGIAR - Strengthening the Partnership, CGIAR Secretariat.

Schmidhuber, J. \& Tubiello, F. N. (2007) Global food security under climate change. PNAS, 104, 19703-19708.

Sierra, K. et al. (2008) Change Update - Transformation of the CGIAR. CGIAR. Brief No.1

GLOPAN (2020) Future Food Systems: For people, our planet and prosperity https://foresight.glopan.org/. Accessed on 24 Dec 2020.

United Nations (2019a) The Sustainable Development Goals Report 2019. https://unstats.un.org/sdgs/report/2019/TheSustainable-Development-Goals-Report-2019.pdf. Accessed on 24 Dec 2020.

United Nations (2019b) World Population Prospects 2019. https://population.un.org/wpp. Accessed on 24 Dec 2020.

UNCTAD (2012) Development and Globalization 2012: Facts and Figures. United Nations Publication.

Willet, W. et al. (2019) Food in the Anthropocene: the EATLancet Commission on healthy diets from sustainable food systems. The Lancet, 393, 447-492. 